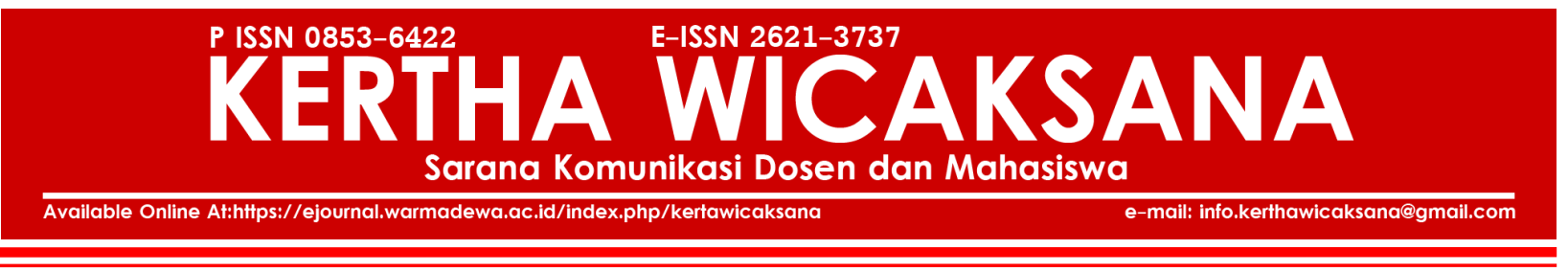

\title{
Kajian Kriminologis Tindak Pidana Pencabulan terhadap Anak di Wilayah Hukum Polresta Denpasar
}

\author{
Ida Bagus Gede Subawa dan Putu Sekarwangi Saraswati \\ Fakultas Hukum Universitas Mahasaraswati, Denpasar, Bali-Indonesia \\ sekarwangisaraswati@gmail.com
}

Published: 25/07/2021

How To Cite:

Subawa, I. B. G., \& Saraswati, P . S. (2021). Kajian Kriminologis Tindak Pidana Pencabulan terhadap Anak di Wilayah Hukum Polresta Denpasar. KERTHA WICAKSANA: Sarana Komunikasi Dosen dan Mahasiswa. 15(2). Pp 169-178. https://doi.org/10.22225/kw.15.2.2021.169-178

\begin{abstract}
Abstrak
Kejahatan atau tindak pidana merupakan persoalan yang dialami manusia dari waktu ke waktu, mengapa tindak pidana dapat terjadi dan bagaimana pemberantasnya merupakan persoalan yang tiada hentinya diperdebatkan, salah satunya adalah tindak pidana pencabulan terhadap anak. Terdapat beberapa faktor tindak pidana pencabulan terhadap anak yakni adanya kemajuan teknologi yang tidak saja membawa dampak positif tetapi juga negatif. Berdasarkan uraian tersebut maka ditarik permasalahan sebagai berikut : yaitu untuk mengetahui faktor penyabab terjadinya tindak pidana pencabulan terhadap anak dan upaya penanggulangan yang dilakukan oleh Polresta Denpasar. Penelitian ini merupakan penelitian hukum empiris, penelitian hukum empiris beranjak dari adanya kesenjangan antara teori dan realita. Metode-metode pendekatan yang digunakan yakni pendekatan kriminologis, pendekatan kasus, dan pendekatan fakta. Faktor penyebab terjadinya tindak pidana pencabulan terhadap anak di Wilayah Hukum Polresta Denpasar disebabkan oleh faktor internal dan faktor eksternal. Faktor internal disebabkan adanya kelainan seksual yang ada dalam diri pelaku, sedangkan faktor eksternal disebabkan karena kurangnya perhatian dari orang tua terhadap anak, faktor ekonomi, faktor lingkungan, faktor teknologi, faktor minuman beralkohol. Upaya penanggulangan tindak pidana pencabulan terhadap anak di wilayah hukum Polresta Denpasar dilakukan melalui upaya penanggulangan preventif dan upaya penanggulangan represif.
\end{abstract}

Kata Kunci: Tindak Pidana; Pencabulan; Anak

\begin{abstract}
A crime or a criminal act is a problem that affect humans from time to time, why the commission of a crime can be happening and what pemberantasnya is a problem that little disputed, one of which is of sexual crimes against children. There are several factors of sexual crimes against children the progress in technology that is not only give positive impact but is also negative. Based on the discussion it can problems: is as follows, aims to review the penyabab the pencabulan crimes against children and prevention efforts made by Polresta Denpasar. The research is empirical legal research, empirical research law pull yourself out of the gap between the theory and reality. The method used that is kriminologis approach, approach case, and approach facts. The cause of the factors of sexual crimes against children in the jurisdiction of polresta denpasar caused by internal and external factors. The internal factor caused by existence of in all the world inside of an offender, while the external factor because lack of attention from the parents against children, economic factors, environmental factor, technology factors, factors of alcoholic beverages. The effort to reduce of sexual crimes against children in the jurisdiction of Polresta Denpasar carried out through .
\end{abstract}

Keywords: Crimes; Sexual; Children.

\section{PENDAhuluan}

Tindak pidana merupakan problema manusia, yang mana terjadi pada seorang yang tidak menggunakan akal serta ditambah dengan dorongan hawa nafsu dalam bertindak, sehingga terjadilah kejahatan yang melampaui batas seperti kejahatan seksual. Kejahatan Seksual yang cukup kiranya untuk menggambarkan bahwa diskriminasi terhadap perempuan bukan hanya dijumpai dalam novel tetapi juga terjadi di 
Indonesia. Diskriminasi yang menimpa perempuan secara fisik meliputi perkosaan dan pencabulan (Widyastuti, 2009). Permasalahan hukum yang penting untuk dikaji secara mendalam salah satunya adalah tindak pidana pencabulan. Tindak pidana pencabulan dalam kenyataannya lebih banyak menimpa kaum perempuan, baik itu anak dan dewasa, dan merupakan perbuatan yang melanggar norma sosial, yaitu kesopanan, agama dan kesusilaan.

Terdapat beberapa faktor mengapa tindak pidana pencabulan terhadap anak semakin sering ditemui di Indonesia salah satunya adanya kemajuan teknologi yang membawa dampak positif dan negatif. Dampak positif perkembangan teknologi telah menyebabkan dunia menjadi tanpa batas dan menyebabkan perubahan struktur sosial masyarakat yang secara signifikan berlangsung dengan cepat. Dampak negatif dari kemajuan teknologi berupa maraknya porno aksi dan pornografi yang dapat dengan mudah diakses melalui internet (Puspitosari, 2010).

Pornografi dalam Black's Law Dictionary adalah material (such as writing, photographs, erotic movies) depicting sexual activityor erotic behavior in a way that is designed to arouse sexual excitement (Garner, 1999). (materi (seperti menulis, fotografi, film erotis) menggambarkan aktivitas seksual dari perilaku erotis dengan cara yang dirancang untuk membangkitkan gairah seksual). Hal ini mengakibatkan kerusakan moral masyarakat Indonesia dan hal ini pula menjadi salah satu sebab maraknya kasus-kasus kriminal berupa pencabulan ataupun pelecehan seksual di negeri ini.

Semakin meningkatnya kriminalitas di Indonesia berakibat timbulnya berbagai macam modus operandi dalam terjadinya tindak pidana. Disamping itu, kurangnya pengetahuan masyarakat tentang hukum pidana menyebabkan seorang menjadi korban perbuatan pidana atau seorang pelaku pidana. Tindak pidana pencabulan merupakan suatu jenis tindak pidana yang berkaitan dengan aktifitas seksual seseorang dengan orang lain yang tidak berdaya, seperti anak-anak atau perempuan (Sulisrudatin, N, 2018).

Child sexual abuse remains largely hidden with many victims waiting years before telling anyone. Research suggests that one in three children who have been sexually abuse do not report it at te time (Allnock D et. al., 2009). (kekerasan seksual pada anak mengalami peningkatan dikarenakan banyak korban yang menunggu bertahun-tahun sebelum memberitahu orang lain. Menurut penelitian satu dari tiga anak yang mengalami kekerasan seksual tidak pernah melaporkan kejadian itu).

Pencabulan adalah jenis kejahatan yang berdampak sangat buruk terutama pada korbannya, sebab pencabulan akan melanggar Hak Asasi Manusia serta dapat merusak martabat kemanusiaan, khususnya terhadap jiwa, akal dan keturunan. Korban dalam kejahatan ini seringkali adalah anak-anak, seperti pada kasus pencabulan yang terjadi di Wilayah Hukum Polresta Denpasar yang dilakukan terdakwa Martinus Doko alias Om Martin dinyatakan terbukti bersalah melakukan pencabulan terhadap anak, membujuk anak untuk melakukan atau membiarkan dilakukan perbuatan cabul. Terdakwa memainkan aksinya terhadap anak yang berinisial $\mathrm{N}$ (9) dengan iming-iming uang $\mathrm{Rp} 5.000,-$. Karena kepolosannya, korban yang masih anak ini pun menuruti keinginan bejat terdakwa. Perbuatan tersebut pun berlanjut hingga pada akhirnya ayah korban memergoki terdakwa sedang mencabuli korban dan melaporkan kasus tersebut ke kantor polisi (Bali Post, 2017).

Berikut adalah contoh kedua kasus pencabulan yang terjadi di Wilayah Hukum Polresta Denpasar yang dilakukan oleh Yuswanto alias Yus (29) dan harus mempertanggungjawabkan perbuatan bejatnya di mata hukum. Perbuatan tak terpuji pelaku bermula ketika saksi korban sebut saja saja Bunga betemu dengan pelaku yang sedang menjual buah di pinggir jalan Tukad Citarum Denpasar, dengan iming-iming uang Rp 5000,- pelaku mengajak korban ke semak-semak dan langsung ditolak oleh korban. Namun secara tiba-tiba terdakwa menarik tangan korban dan diajak ke semak-semak. Setiba di semak-semak itu, terdakwa langsung menjamah tubuh korban yang masih duduk bangku kelas 2 SMP ini. Mulanya korban sempat melawan namun karena terdakwa terus memaksa sembari mengancam akhirnya korban pasrah. Pada saat korban melakukan aksi bejatnya, tiba-tiba ayah korban datang dan langsung mengamankan anaknya. Selanjutnya pelaku dibawa ke kantor polisi untuk diproses secara hukum (Bali News Network, 2018).

Kitab Undang-Undang Hukum Pidana (selanjutnya disebut KUHP) mengatur tindak pidana pencabulan termasuk dalam kejahatan 
terhadap kesusilaan dalam bab XIV yang dimulai dari Pasal 281 sampai dengan 303 KUHP. Terkait dengan perbuatan cabul yang dilakukan oleh pelaku akan mendapatkan hukuman, sebagaimana yang tercantum dalam Pasal 289 sampai dengan 296 KUHP. Pasal 289 KUHP menyatakan "Barang siapa dengan kekerasan atau ancaman kekerasan memaksa seorang untuk melakukan atau membiarkan dilakukan perbuatan cabul, diancam karena melakukan perbuatan yang menyerang kehormatan kesusilaan, dengan pidana penjara paling lama sembilan tahun”.

Tindak pidana pencabulan terhadap anak diatur khusus dalam Undang-undang Nomor 17 Tahun 2016 Lembaran Negara Republik Indonesia Tahun 2016 Nomor 99 dan Tambahan Lembaran Negara Republik Indonesia Nomor 5882 tentang Perubahan Kedua Atas UndangUndang Nomor 23 Tahun 2002 tentang Perlindungan Anak (selanjutnya disebut UndangUndang Perlindungan Anak) tertuang dalam Pasal 76E Undang-Undang Perlindungan Anak, yang menyebutkan "Setiap orang dilarang melakukan kekerasan atau ancaman kekerasan, memaksa, melakukan tipu muslihat, melakukan serangkaian kebohongan, atau membujuk anak untuk melakukan atau membiarkan dilakukan perbuatan cabul".

Pasal 82 Undang-Undang Perlindungan Anak, menyatakan sanksi bagi pelaku pencabulan terhadap anak sebagai berikut:

Setiap orang yang melanggar ketentuan sebagaimana dimaksud dalam Pasal 76E dipidana dengan pidana penjara paling singkat 5 (lima) tahun dan paling lama 15 (lima belas) tahun dan denda paling banyak Rp5.000.000.000,00 (lima miliar rupiah).

Dalam hal tindak pidana sebagaimana dimaksud pada ayat (1) dilakukan oleh Orang Tua, Wali, pengasuh Anak, pendidik, atau tenaga kependidikan, maka pidananya ditambah $1 / 3$ (sepertiga) dari ancaman pidana sebagaimana dimaksud pada ayat (1).

Berdasarkan ketentuan Pasal yang telah dipaparkan tersebut, maka seseorang telah dapat dikatakan melakukan suatu tindak pidana pencabulan yang dimana telah memenuhi unsurunsur yang dirumuskan dalam KUHP maupun Undang-Undang Perlindungan Anak, yaitu dengan sengaja serta melakukan kekerasan atau ancaman kekerasan, memaksa, melakukan tipu muslihat, serangkaian kebohongan atau membujuk anak untuk melakukan atau membiarkan dilakukan perbuatan cabul.

Guna mencegah terjadinya kasus pencabulan terhadap anak, keluarga beserta seluruh lapisan masyarakat turut berperan aktif dalam memperhatikan, melindungi dan menjaga dari perlakuan-perlakuan seperti, diskriminasi, eksploitasi, penelantaran, kekejaman dan ketidakadilan (Bayu, 2020).

Penjelasan mengenai latar belakang menjadi suatu dasar maupun gambaran permasalahan terkait pengaturan pengeaturan tindak pidana pencabulan serta beberapa contoh kasus di Denpasar yang kemudian dirumuskan lagi secara kongkrit permasalahan tersebut kedalam 2 (dua) rumusan masalah pada jurnal ilmiah ini yaitu mengenai Faktor-faktor apakah yang menjadi penyebab terjadinya tindak pidana pencabulan terhadap anak di Wilayah Hukum Polresta Denpasar ? dan Bagaimana upaya penanggulangan oleh Polresta Denpasar terkait tindak pidana pencabulan terhadap anak ?

Tujuan daripada jurnal ilmiah ini dibagi menjadi tujuan umum serta tujuan khusus, adapun tujuan umum daripada jurnal ilmiah ini yaitu guna mengetahui kajian kriminologis tindak pidana pencabulan terhadap anak. Tujuan khusus yang menjadi konsen pada jurnal ilmiah ini yaitu untuk mengetahui Faktor-faktor apakah yang menjadi penyebab terjadinya tindak pidana pencabulan terhadap anak serta upaya penanggulangannya.

\section{METODE}

Jurnal ilmiah ini menggunakan penelitian hukum empiris yang dimana hukum dikonsepkan sebagai suatu gejala empiris yang dapat diamati dalam kehidupan nyata (Rahmawati, Yuliartini., \& Mangku, 2021). Jurnal ilmiah ini menggunakan pendekatan kriminologis, pendekatan kasus dan pendekatan fakta. Pendekatan Kriminologis bertujuan mempelajari kejahatan yang diartikan sebagai pola tingkah laku yang merugikan masyarakat, baik secara fisik maupun materi, baik yang dirumuskan dalam hukum maupun tidak. Pendekatan kasus (the case approach) dilakukan dengan cara meneliti kasus-kasus yang telah terjadi di wilayah Polresta Denpasar dan pendekatan fakta (the fact approach) digunakan dengan mengadakan penelitian terhadap data dan wawancara langsung terhadap pihak-pihak terkait.

\section{HASIL DAN PEMBAHASAN}




\section{Faktor-Faktor Penyebab Terjadinya Tindak Pidana Pencabulan Terhadap}

Kejahatan atau tindak pidana yang dimaksud adalah tindak pidana perbuatan cabul yang dilakukan oleh orang dewasa dan korbannya disini adalah anak, seorang anak seharusnya dilindungi sebagai tunas bangsa, merupakan generasi penerus dalam pembangunan bangsa dan Negara (Fauzi, 2020). Berikut akan ditampilkan data tindak pidana perbuatan cabul yang terjadi di Kota Denpasar periode tahun 2018:

Tabel 1

Data Kasus Pencabulan tahun 2018

\begin{tabular}{|c|c|c|c|c|}
\hline No & Nama Pelaku (Umur) & Tahun & Bentuk Perbuatan & Sanksi Pidana \\
\hline 1 & $\begin{array}{c}\text { I Ketut Suweta Tanaya } \\
\text { (49 tahun) }\end{array}$ & 2018 & $\begin{array}{l}\text { Melakukan pencabulan } \\
\text { terhadap anak dengan } \\
\text { cara membujuk anak } \\
\text { dengan iming-iming } \\
\text { uang sebesar Rp. } 15.000 \\
\text { (lima belas ribu rupiah) }\end{array}$ & $\begin{array}{c}\text { Pidana penjara selama } 8 \\
\text { (delapan) tahun dan denda sebe- } \\
\text { sar RP. } 100.000 .000 \text { (seratus juta } \\
\text { rupiah). }\end{array}$ \\
\hline 2 & $\begin{array}{l}\text { Andhika Akbar } \\
\text { (22 tahun) }\end{array}$ & 2018 & $\begin{array}{l}\text { Melakukan pencabulan } \\
\text { terhadap anak, dengan } \\
\text { cara membujuk seorang } \\
\text { anak untuk melakukan } \\
\text { perbuatan cabul. }\end{array}$ & $\begin{array}{l}\text { Pidana penjara selama } 5 \text { (lima) } \\
\text { tahun dan pidana denda sebesar } \\
\text { RP. 5.000.000 (lima juta rupiah). }\end{array}$ \\
\hline 3 & $\begin{array}{l}\text { Moch. Yatim } \\
\text { (69 tahun) }\end{array}$ & 2018 & $\begin{array}{l}\text { Melakukan pencabulan } \\
\text { terhadap anak, dengan } \\
\text { cara membujuk anak } \\
\text { untuk melakukan per- } \\
\text { buatan cabul. }\end{array}$ & $\begin{array}{l}\text { Pidana penjara selama } 6 \text { (enam) } \\
\text { tahun dan pidana denda sebesar } \\
\text { RP. 200.000.000 (dua ratus juta } \\
\text { rupiah). }\end{array}$ \\
\hline 4 & $\begin{array}{l}\text { Taufiq Anwar } \\
\text { (22 tahun) }\end{array}$ & 2018 & $\begin{array}{l}\text { Melakukan pencabulan } \\
\text { terhadap anak. }\end{array}$ & $\begin{array}{c}\text { Pidana penjara selama } 5 \text { (lima) } \\
\text { tahun dan pidana denda sebesar } \\
\text { RP. 5.000.000.000.000 (lima } \\
\text { milyar rupiah). }\end{array}$ \\
\hline 5 & $\begin{array}{l}\text { Dedy Hidayat } \\
\text { (39 tahun) }\end{array}$ & 2018 & $\begin{array}{l}\text { Melakukan pencabulan } \\
\text { terhadap anak, dengan } \\
\text { cara membujuk anak. }\end{array}$ & $\begin{array}{c}\text { Pidana penjara selama } 8 \\
\text { (delapan) tahun dan pidana denda } \\
\text { sebesar RP. 200.000.000 (dua } \\
\text { ratus juta rupiah). }\end{array}$ \\
\hline
\end{tabular}

Lima kasus yang terjadi pada tahun 2018 di Wilayah Hukum Polresta Denpasar ini memiliki sanksi pidana penjara maupun denda yang berbeda-beda. Berdasarkan wawancara langsung dengan Angeliky Handajani Day selaku Hakim Pengadilan Negeri di Denpasar (Pada tanggal 24 Maret 2021), terhadap pelaku tindak pidana pencabulan terhadap anak terkait perbedaan dalam penjatuhan masa hukuman pidana penjara menyebutkan beberapa pertimbangan yang dapat dijadikan pertimbangan dalam menjatuhkan sanksi pidana tersebut yaitu dengan lebih mempertimbangkan aspek yuridis dan non yuridis yang ada pada perkara tersebut.

Setiap putusan hakim, mengandung dua unsur yaitu legal justice dan moral justice. Legal justice artinya setiap putusan hakim harus sesuai dengan peraturan perundang-undangan dan moral justice artinya setiap putus hakim harus sesuai dengan rasa keadilan yang ada dalam masyarakat. Terkait dengan pertimbangan tersebut secara peraturan perundang-undangan di Indonesia biasanya setiap putusan minimum dari isi yang di tegaskan pada Pasal terkait pemidanaan kasus perbuatan cabul terhadap anak oleh hakim tentunya akan menggunakan ketentuan Pasal 197 Ayat (1) huruf f Undang-Undang Nomor 8 Tahun 1981 Tentang Hukum Acara Pidana (selanjutnya disebut KUHAP) sebagai aturan pokok yang menyebutkan bahwa "Pasal peraturan perundangundangan yang menjadi dasar pemidanaan atau tindakan dan Pasal peraturan perundangundangan yang menjadi dasar hukum dari putusan, disertai keadaan yang memberatkan dan yang meringankan terdakwa" ditambahkan kembali didasarkan pada Pasal 8 ayat (2) Undang -undang Nomor 48 Tahun 2009 Lembaran Negara Nomor 157, Tambahan Lembaran Negara Republik Inndonesia Nomor 5076 tentang Kekuasaan Kehakiman sebagai aturan yang menyebutkan bahwa "Dalam mempertimbangkan 
berat ringannya pidana, hakim wajib memperhatikan pula sifat yang baik dan jahat dari terdakwa."

Berdasarkan penjelasan Pasal disebutkan, "dalam menentukan berat ringannya pidana yang akan dijatuhkan, hakim wajib memperhatikan sifat baik atau sifat jahat dari terdakwa sehingga putusan yang dijatuhkan sesuai dan adil dengan kesalahan yang dilakukannya." Sehingga setiap menjatuhkan putusan dengan sanksi minimum terhadap pelaku tindak pidana pencabulan terhadap anak di Pengadilan Negeri Denpasar di persidangan dilakukan dengan menemukan unsurunsur yang dapat meringankan, baik yang berkaitan dengan prilaku keterbukaan, kejujuran, tidak berbelit-belit, mengakui kesalahan, latar belakang dan psikologi keseharian pelaku yang baik dan kooperatif dimuka persidangan, begitu sebaliknya akan diterapkan putusan dengan sanksi maksimum yang berarti sedikit tidaknya jika ketentuan dari Pasal tersebut diatas tidak tercerminkan dimuka persidangan.

Faktor penyebab terjadinya tindak pidana pencabulan terhadap anak dibagi menjadi dua, yakni faktor internal dan faktor eksternal. Data didapatkan berdasarkan wawancara dengan narasumber dari psikolog dan kepolisian. Penulis melakukan wawancara dengan I Putu Galang Dharma Putra, S.Psi., M.Psi (Pada tanggal 26 Maret 2021) yang merupakan Psikolog di P2TP2A (Pusat Pelayanan Terpadu Pemberdayaan Perempuan dan Anak) Kota Denpasar yang pernah langsung menangani kasus pada pelaku dan korban tindak pidana pencabulan terhadap anak menyebutkan mengenai kasus tindak pidana pencabulan terhadap anak yang terjadi di Wilayah Hukum Polresta Denpasar, menurutnya faktor internal yang menyebabkan pelaku melakukan tindak pidana pencabulann terhadap anak dikarenakan adanya kelainan seksual atau biasa disebut paraphilia yang menyimpang seperti pelaku memiliki orientasi seksual terhadap anak (pedofilia). Pelaku yang memiliki kelainan seksual terhadap anak tertarik untuk melampiaskan nafsu seksualnya kepada anak pra pubertas. Pelaku dapat dikatakan memiliki perilaku yang abnormal, yang seharusnya memberikan rasa kasih sayang terhadap anak namun hal itu menjadi nafsu seksual atau orientasi seksual kepada anak. Perilaku pelaku ini dapat dikategorikan karena adanya tekanan mental dan gangguan kepribadian pada diri pelaku. Pelampiasan nafsu seksual oleh orang dewasa yang memiliki kelainan orientasi seksual merupakan suatu kebutuhan yang harus dipenuhinya sehingga mendorong pelaku untuk melakukan perbuatan cabul dengan anak-anak.

Pelaku pencabulan terhadap anak biasanya menunjukkan perilaku tertentu jika ingin menjadikan anak-anak sebagai target, pelaku akan melakukan pendekatan kepada anak, seperti memberikan perhatian yang berlebihan kepada anak tersebut. Kejadian ini harus diperhatikan dan diwaspadai oleh orang tua anak tersebut. Pelaku biasanya menunjukkan sifat sayang yang berlebihan terhadap anak, serta ramah hingga akhirnya membuat anak tersebut percaya terhadap pelaku dan membiarkan pelaku melakkukan aksinya baik itu meraba payudara ataupun menyentuh kelamin anak. Kebanyakan pelaku pencabulan terhadap anak ini merupakan orang terdekat dari anak tersebut, baik itu kakek, paman, pengasuh, ataupun tetangga anak tersebut. Ironisnya bahkan anak tersebut tidak sadar bahwa dirinya telah menjadi korban pencabulan yang dilakukan oleh orang dewasa dan diketahuinya perbuatan pencabulan terhadap anak ini berdasarkan cerita polos anak kepada orang tuanya.

Wawancara selanjutnya dilakukan untuk mengetahui faktor eksternal penyebab pelaku melakukan tindak pidana pencabulan terhadap anak, faktor eksternal ini berasal dari luar diri pelaku dan bukan berasal dari dirinya sendiri. Menurut Josina Lambiombir, SH., S.IK (Pada tanggal 09 Mei 2019) selaku Kanit PPA Resta Denpasar yang pernah menangani kasus tindak pidana pencabulan terhadap anak mengatakan bahwa faktor eksternal penyebab terjadinya kasus tindak pidana pencabulan terhadap anak di Wilayah Hukum Polresta Denpasar adalah sebagai berikut:

Kurangnya Kurangnya Perhatian Dari Orang Tua Terhadap Anak

Perhatian dan kasih sayang dari orang tua merupakan hal terpenting berperan dalam tumbuh kembang anak. Anak yang dalam masa tumbuh dan berkembang memerlukan sosok yang dapat menjadi panutan, peran orang tualah yang lebih besar terhadap tumbuh kembang pada diri anaknya, sehingga anak dapat terhindar dari perilaku-perilaku yang menyimpang. Kurangnya perhatian dari orang tua terhadap anak dapat memicu anak menjadi korban dari tindak pidana pencabulan, apalagi orang tua di daerah yang 
tergolong tingkat ekonomi bawah lebih mengutamakan untuk memenuhi kebutuhan hidup sehari-hari mereka dan fokus pada pekerjaannya daripada memberikan pengawasan kepada anaknya, sehingga kesempatan ini dapat menjadi celah bagi pelaku untuk melakukan pendekatan ke anak tersebut. Kesempatan tersebut dapat menjadi peluang bagi para pelaku tindak pidana pencabulan untuk melakukan pendekatan sampai terjadinya tindakan pencabulan terhadap anak.

\section{Faktor Ekonomi}

Faktor ekonomi korban merupakan salah satu faktor penyebab pelaku melakukan tindak pidana pencabulan terhadap anak, keadaaan ekonomi yang dimiliki keluarga belum dapat mencukupi beberapa hal yang diinginkan oleh anak. Pelaku pencabulan memiliki pandangan untuk menyasar keluarga yang tingkat perekonomiannya termasuk dalam kelas ekonomi bawah. Kebaikan dan bantuan secara ekonomi yang diberikan kepada anak dan keluarganya memberikan pandangan bahwa pelaku merupakan orang baik. Kesempatan inilah yang dimanfaatkan pelaku untuk melakukan pendekatan kepada anak, agar pelaku dapat melakukan perbuatan cabulnya kepada anak tersebut, dan karena dengan imingiming terhadap uang dapat membuat pelaku dengan mudahnya melakukan pencabulan terhadap anak.

\section{Faktor Lingkungan}

Faktor lingkungan juga dapat menjadi faktor terjadinya tindak pidana pencabulan terhadap anak. Pengaruh yang diberikan dalam lingkungan keluarga maupaun lingkungan sosial dapat menyebabkan perubahan pada diri anak. seperti contoh bahwa orangtua merupakan pengaruh lingkungan yang pertama didapat oleh seorang anak sebelum anak tersebut mengenal lingkungan luar disekitar tempat tinggalnya. Oleh karena itu lingkungan pertama yang dia serap adalah lingkungan keluarga itu sendiri. Keluarga yang baik, yang baik juga ditiru sianak, dan sebaliknya. Apabila anak tidak tumbuh dalam lingkungan keluarga yang baik, maka anak akan mengalami trauma sehingga rentan menjadi korban pencabulan. Apabila anak pernah menjadi korban pencabulan pada masa anak-anak juga dapat membentuk perilaku yang buruk dan membuat anak tersebut meniru untuk melakukan pencabulan pada saat ia telah dewasa dan jika tidak mendapat penanganan yang baik dalam lingkungan keluarga maupun sosial di masyarakat maka hal ini akan memperburuk keadaan dikemudian hari.

\section{Faktor Teknologi}

Faktor perkembangan teknologi tidak hanya memberikan dampak positif tetapi juga dapat memberikan dampak yang negatif. Penyerapan kemajuan teknologi merupakan dampak globalisasi yang kini masuk ke Indonesia. Dampak negatif dari penyerapan berlebihan perkembangan teknologi itu bisa menjadi disalah gunakan oleh anak-anak maupun orang dewasa. Di tengah-tengah masyarakat, dampak globalisasi perkembangan teknologi bisa menghilangkan nilai-nilai dan norma-norma yang ada di tengahtengah masyarakat sehingga dapat menimbulkan penyimpangan-penyimpangan perilaku. Semakin tinggi penyalahgunaan dampak globalisasi perkembangan teknologi tersebut, semakin tinggi pula tingkat terjadinya tindak pidana yang disebabkan oleh teknologi itu seperti tindak pidana pencabulan.

Bahkan dengan perkembangan teknologi seperti saat ini memudahkan seseorang untuk mengakses situs-situs yang berbau pornografi, seperti berupa gambar-gambar, video, dan ada pula yang menyajikan gambar maupun video porno dengan anak-anak. Adegan gambar maupun video dan sebagainya dapat mengakibatkan timbulnya keinginan pelaku untuk melakukan adegan dalam video porno. Seseorang yang terbiasa menikmati porografi khususnya pornografi anak-anak secara tidak langsung akan membentuk orientasi seksual seseorang menjadi menyimpang. Sehingga dengan terbentuknya suatu orientasi seksual yang menyimpang inilah yang menyebabkan pelaku akan mencobanya secara langsung terhadap anak, seperti melakukan perbuatan cabul untuk memenuhi orientasi seksualnya.

\section{Faktor Minuman Beralkohol}

Minuman beralkohol atau yang biasa disebut dengan minuman keras atau miras dapat mempengaruhi seseorang melakukan tindak pidana pencabulan, minuman beralkohol dapat memberikan efek seseorang menjadi mabuk atau tidak mampu mengendalikan dirinya sendiri dan cenderung membawa seseorang nekat untuk melakukan tindak pidana. Seseorang yang mengkonsumsi minuman keras membuatnya berani untuk melakukan tindak pidana pencabulan dan tidak merasakan yang namanya malu untuk melakukan tindak pidana pencabulan 
itu karena ilusi yang ditimbulkan oleh minuman keras.

\section{Upaya Penanggulangan Tindak Pidana Pencabulan Terhadap Anak Di Wilayah Hukum Polresta Denpasar}

Kejahatan atau tindak kriminal merupakan salah satu bentuk dari perilaku menyimpang yang selalu ada dan melekat pada tiap bentuk masyarakat, tidak ada masyarakat yang sepi dari kejahatan (Muliadi, 2012). Dilakukan upaya penanggulangan demi mencegah dan menanggulangi kejahatan yang ada didalam masyarakat, upaya penanggulangan adalah upaya yang dilakukan untuk mencegah, menghadapi, atau mengatasi suatu keadaan atau masalah yang dapat meresahkan ataupun membahayakan masyarakat baik meresahkan masyarakat individu ataupun kelompok.

Upaya penanggulangan preventif dan represif merupakan cara yang dilakukan untuk menanggulangi sebelum terjadinya kejahatan dan sesudah terjadinya kejahatan. Penanggulangan kejahatan secara preventif dilakukan untuk mencegah terjadinya atau timbulnya kejahatan yang pertama kali. Mencegah kejahatan lebih baik daripada mencoba untuk mendidik penjahat menjadi lebih baik kembali, sebagaimana semboyan dalam kriminologi yaitu usaha-usaha memperbaiki penjahat perlu diperhatikan dan diarahkan agar tidak terjadi lagi kejahatan ulangan (Christie., Yuliartini, \& Mangku, 2021).

Berdasarkan wawancara dengan Josina Lambiombir, SH., S.IK (Pada tanggal 25 Maret 2021) selaku Kanit PPA Resta Denpasar, usaha penanggulangan preventif yang dilakukan Polresta Denpasar dalam menanggulangi tindak pidana pencabulan terhadap anak yaitu dengan cara:

Pihak Kepolisian melakukan sosialiasi ke sekolah-sekolah baik Sekolah Dasar (SD), Sekolah Menengah Pertama (SMP), dan Sekolah Menengah Atas (SMA) mengenai tindak pidana pencabulan, sosialisasi ini diharapkan akan dapat menambah wawasan dan pemahaman siswa dan siswi, agar mereka bisa saling menjaga dan mengingatkan sesama teman. Pihak Kepolisian juga melakukan sosialisasi ke desa-desa melalui perangkat desa untuk memberi pemahaman mengenai tindak pidana pencabulan dan menghimbaukan agar para orang tua yang masih memiliki anak yang masih kecil lebih memperhatikan anak-anaknya tersebut, karena bisa saja anak tersebut menjadi salah satu korban yang dilakukan oleh orang terdekat.

Pihak Kepolisian bekerjasama dengan tokoh agama untuk dapat membina masyarakat dalam memahami norma-norma yang ada di masyarakat agar terhindar dari hal-hal negatif. Pihak Kepolisian juga bekerjasama dengan Pecalang di setiap desa agar selalu waspada dan melakukan patroli di sejumlah titik dan wilayah-wilayah yang rentan dilakukannya kejahatan, salah satu contohnya kasus pencabulan yang banyak terjadi, dan Pihak Kepolisian bekerjasama dengan Satuan Polisi Pamong Praja (Satpol PP) dalam merazia beberapa penginapan ataupun hotel yang ada di Denpasar agar tidak memberikan ruang gerak bagi seseorang untuk melakukan perbuatan cabul

Pihak Kepolisian melakukan razia dan juga penyitaan terhadap barang-barang yang berbau pornografi, seperti berupa gambar, cd, dan lain lain. Hal ini tidak terlepas dari kemajuan teknologi yang ada dan ini dilakukan agar tindak pidana pencabulan dapat diminimalisir. Pihak Kepolisian juga melakukan razia minuman keras, dikarenakan minuman keras dapat memberikan efek seseorang menjadi mabuk atau tidak mampu mengendalikan dirinya sendiri dan cenderung membawa seseorang nekat untuk melakukan tindak pidana, termasuk juga tindak pidana pencabulan dan yang menjadi korbannya adalah anak.

Meningkatkan keamanan di seluruh wilayah hukum Polresta Denpasar terutama daerah pariwisata guna mencegah serta menindak apabila ada daerah yang terindikasi terdapat tindak pidana pencabulan terhadap anak.

Upaya preventif yang dilakukan oleh pihak kepolisian Polresta Denpasar sesuai dengan wewenang yang dimiliki kepolisian yaitu melakukan upaya preventif agar tidak terjadi suatu tindak pidana pencabulan terhadap anak. Kepolisian sesuai fungsinya yakni pemelihara keamanan dan ketertiban masyarakat, penegakan hukum, perlindungan, pengayoman dan pelayanan kepada masyarakat adalah institusi yang paling bertanggung jawab dalam penanggulangan kejahatan (Guntur, 2017).

Upaya penanggulangan represif kejahatan adalah upaya yang menitikberatkan pada jalur penal. Tindakan represif merupakan tindakan penegakan hukum mulai dari penyelidikan, penyidikan sampai ke pengadilan (Bawono \& Mashdurohatun 2021). Berdasarkan wawancara 
dengan Josina Lambiombir, SH., S.IK (Pada tanggal 25 Maret 2021) selaku Kanit PPA Resta Denpasar, upaya penanggulangan represif yang dilakukan oleh Polresta Denpasar yaitu dengan melakukan penyelidikan dan penyidikan terhadap pelaku yang melakukan tindak pidana pencabulan terhadap anak. Adapun serangkaian upaya penindakan yang dilakukan Unit Perlindungan Perempuan dan Anak antara lain :

Selalu menerima laporan atau pengaduan mengenai suatu tindak pidana pencabulan terhadap anak ke Polresta Denpasar. Sesuai dengan Pasal 24 KUHAP yang menjelaskan laporan adalah pemberitahuan yang disampaikan oleh seseorang karena hak dan kewajiban berdasarkan undang-undang kepada pejabat yang berwenang tentang telah atau sedang atau diduga akan terjadinya peristiwa pidana. Sedangkan Pasal 25 KUHAP menjelaskan bahwa pengaduan adalah pemberitahuan disertai permintaan oleh pihak yang berkepentingan kepada pejabat yang berwenang untuk menindak menurut hukum seseorang yang telah melakukan tindak pidana aduan yang merugikannya.

Kepolisian Polresta Denpasar akan melakukan penyelidikan ke Tempat Kejadian Perkara (TKP) yang dilakukan oleh penyelidik sesuai dengan Pasal 5 KUHAP yang karena kewajibannya mempunyai wewenang untuk:

menerima laporan atau pengaduan dari seorang tentang adanya tindak pidana;

\section{mencari keterangan dan barang bukti;}

menyuruh berhenti seseorang yang dicurigai dan menanyakan serta memeriksa tanda pengenal diri;

mengadakan tindakan lain menurut hukum yang bertanggungjawab.

Setelah itu atas perintah penyidik dapat melakukan tindakan berupa:

penangkapan, larangan meninggalkan tempat, penggeledahan dan penyitaan;

pemeriksaan dan penyitaan surat;

mengambil sidik jari dan memotret seseorang;

membawa dan menghadapkan seseorang pada penyidik.

Apabila saksi korban masih dibawah umur, dalam pemeriksaan yang dilakukan terhadapnya wajib untuk didampingi oleh orang tua saksi korban, pihak P2TP2A, dan/atau oleh advokat.

Pemeriksaan di tingkat penyidikan oleh anggota kepolisian dapat melakukan upaya seperti penangkapan, penahanan, penggeledahan, penyitaan dan pemeriksaan surat apabila:

Apabila seorang diduga keras melakukan tindak pidana pencabulan terhadap anak dan telah memenuhi Ketentuan Perundang-Undangan yang mengatur mengenai pencabulan terhadap anak dan berdasarkan bukti permulaan yang cukup dapat dilakukan penangkapan sesuai dengan Pasal 17 KUHAP.

Penangkapan dilakukan oleh petugas kepolisian dengan memperlihatkan surat tugas serta memberikan kepada tersangka surat perintah penangkapan dan harus diberikan kepada keluarganya segera setelah penangkapan.

Penahanan dapat dilakukan penyidik untuk kepentingan penyidikan, penyidik memberikan surat perintah penahanan atau penetapan hakim yang mencantumkan identitas terdakwa dan tembusan surat perintah penahanan harus diberikan kepada keluarganya.

Untuk kepentingan penyidikan, penyidik dapat melakukan penggeledahan rumah atau penggeledahan pakaian atau penggeledahan badan menurut tatacara yang ditentukan dalam KUHAP. Selanjutnya penyitaan hanya dapat dilakukan olehh penyidik dengan surat izin ketua pengadilan negeri setempat, penyitaan terkait dengan benda benda-benda yang berhubungan dengan tindak pidana pencabulan terhadap anak.

Penyidik juga berwenang membuka, memeriksa, menyita, surat-surat yang dikirim lewat pos yang diduga ada hubungan dengan tindak pidana pencabulan terhadap anak. Apabila surat tersebut ada hubungannya dengan perkara yang sedang diperiksa maka surat tersebut akan dilampirkan pada berkas perkara.

Setelah diselesaikannya proses penyelidikan dan penyidikan oleh kepolisian, maka penyidik akan menyerahkan berkas perkara kepada penuntut umum dalam hal ini adalah Jaksa untuk selanjutnya dilakukan penuntutan terhadap terdakwa dimuka persidangan di Pengadilan Negeri Denpasar.

\section{SIMPULAN}

Faktor penyebab terjadinya tindak pidana pencabulan terhadap anak di Wilayah Hukum Polresta Denpasar disebabkan oleh faktor internal 
dan faktor eksternal. Faktor internal penyebab terjadinya tindak pidana pencabulan terhadap anak adalah adanya kelainan seksual atau biasa disebut paraphilia yang menyimpang seperti pelaku memiliki orientasi seksual terhadap anak (pedofilia). Sedangkan faktor eksternal penyebab terjadinya tindak pidana pencabulan terhadap anak terdiri dari 5 (lima) faktor, yaitu seperti kurangnya kurangnya perhatian dari orang tua terhadap anak, faktor ekonomi, faktor lingkungan, faktor teknologi, faktor minuman beralkohol. Upaya penanggulangan secara represif dilakukan melalui jalur penal oleh pihak kepolisian yaitu dengan cara menindak pelaku tindak pidana pencabulan terhadap anak, melakukan penyelidikan dan penyidikan dilanjutkan dengan pelimpahan berkas perkara ke kejaksaan agar pelaku bertanggung jawab atas perbuatannya.

Agar kedepannya upaya-upaya penanggulangan yang dilakukan para penegak hukum lebih ditingkatkan lagi untuk dapat mengurangi jumlah pelaku tindak pidana pencabulan terhadap anak.

Agar kedepannya para penegak hukum lebih sering melakukan sosialisasi kepada masyararakat mengenai faktor-faktor penyebab dan upayaupaya pencegahan terjadinya tindak pidana pencabulan terhadap anak.

\section{DAFTAR PUSTAKA}

Allnock. D, et. al., (2009). Sexual Abuse and Therapeutic Service for Children and Young People: the Gap Between Provision and Need: Full Report, NSPCC, London. Retrieved from https://www.nwgnetwork.org/wp-content/ uploads/2017/11/6c0404f7ea1e4731f4c171d26 19e79b280a3.pdf

Bali Post, (2017). Kasus Pencabulan Anak, Om Martin Divonis 4,5 Tahun Penjara. Retrieved from https://www.balipost.com/ news/2017/10/05/24016/Kasus-PencabulanAnak,Om-Martin...html

Bali News Network, 2018, Cabuli Anak SMP, Pedagang Buah Diadili. Retrieved from http:// balinewsnetwork.com/2018/01/17/cabuli-anaksmp-pedagang-buah-keliling-diadili/

Bayu, A. (2020). Kajian Kriminologis Tindak Pidana Pencabulan Terhadap Anak di Wilayah Hukum Polresta Denpasar. Universitas Udayana.

Bawono, B. T., \& Mashdurohatun, A. (2021). Penegakan Hukum Pidana Di Bidang Illegal Logging Bagi Kelestarian Lingkungan Hidup Dan Upaya Penanggulangannya. Jurnal Hukum, 26(2), h. 606. DOI : http:// dx.doi.org/10.26532/jh.v26i2.211
Christie, S. N., Yuliartini, N. P. R., \& Mangku, D. G. S. (2021). Tinjauan Kriminologis Terhadap Tindak Pidana Pencurian Kendaraan Bermotor di Kota Singaraja. Jurnal Komunitas Yustisia, 4 (1), h. 122. DOI : http://dx.doi.org/10.23887/ jatayu.v4i1.33037

Fauzi, R. (2020). Upaya Penanggulangan Tindak Pidana Pencabulan Terhadap Anak di Kota Padang. Kertha Wicaksana, 14(1), h. 3. DOI : https://doi.org/10.22225/kw.14.1.1529.1-8

Garner, B. A. (1999). Black's Law Dictionary. St. Paul Minn: West Group.

Guntur, M. (2017). Fungsi Kepolisian Negara Dalam Pemeliharaan Keamanan Dan Ketertiban Pada Masyarakat Kota Sengkang Kabupaten Wajo. Al Hikam, 1(3), h. 167. DOI : https:// doi.org/10.36294/pionir.v5i4.916

Muliadi, S. (2012). Aspek Kriminologis Dalam Penanggulangan Kejahatan. Fiat Justisia: Jurnal Ilmu Hukum, 6(1). h. 6. DOI : https:// doi.org/10.25041/fiatjustisia.v6no1.346

Puspitosari, H. (2010). Upaya Penanggulangan Prostitusi Online Internet Berdasarkan UndangUndang Nomor 11 Tahun 2008 Tentang Informasi Dan Transaksi Elektronik (ITE). Surakarta: Jurnal Komunikasi Massa, 3 (1). Retrieved from https:// www.jurnalkommas.com/docs/Upaya $\%$ 20penanggulanagn $\% 20$ Prostitusi $\%$ 20Online.pdf

Rahmawati, E., Yuliartini, N. P. R., \& Mangku, D. G. S. (2021). Penerapan Pertanggungjawaban Pidana Terhadap Pelaku Persetubuhan (Studi Kasus Putusan No. 23/PID. SUS/2020/PN. SGR). Jurnal Komunitas Yustisia, 4 (1), h. 3. DOI : $\quad$ http://dx.doi.org/10.23887/ jatayu.v4i1.33016

Solahudin. (2008). Kitab Undang-Undang Hukum Pidana, Acara Pidana, Dan Perdata, Cet. 1, Jakarta: Visimedia.

Sulisrudatin, N. (2018). Analisis Tindak Pidana Pencabulan Oleh Pelaku Pedofil. Jurnal Ilmiah Hukum Dirgantara, 6(2), h.22. DOI : https:// doi.org/10.35968/jh.v6i2.118

Undang-Undang Republik Indonesia Nomor 17 Tahun 2016 tentang Perubahan Kedua Atas UndangUndang Nomor 23 Tahun 2002 tentang Perlindungan Anak, Dicatatkan pada Lembaran Negara Republik Indonesia Tahun 2016 Nomor 99 dan Tambahan Lembaran Negara Republik Indonesia Nomor 5882.

Undang-Undang Republik Indonesia Nomor 44 Tahun 2008 tentang Pornografi, Dicatatkan pada Lembaran Negara Republik Indonesia Tahun 2008 Nomor 181 dan Tambahan Lembaran Negara Republik Indonesia Nomor 4928.

Widyastuti, A. R. (2009). Peran Hukum dalam Memberikan Perlindungan terhadap Perempuan 
dari Tindak Kekerasan di Era

Globalisasi. Mimbar Hukum-Fakultas Hukum

Universitas Gadjah Mada,21(2), h. 2. DOI :

https://doi.org/10.22146/jmh.16264 